Egypt. Acad. J. biolog. Sci., 2(2): 11 - 20 (2010)

Email: egyptianacademic@yahoo.com

Received: 5/6/2010
C. Physiology \& Molecular Biology

ISSN: 2090-0767

www.eajbs.eg.net

\title{
The Effect of Folic Acid Supplementation on Osteoporotic Markers in Ovariectomized Rats.
}

\author{
Al-Sowyan N. S. and Nadia H. Mahmoud \\ Department of Biology, Faculty of Science, AL-Qassim University \\ P. O. Box: (30230), Buraydah (51744), Saudi Arabia. \\ Email: knaaj1@yahoo.com - Email: nadia-aleryan@live.com
}

\begin{abstract}
Menopause is considered to be a natural change of life, which may be accompanied by various health problems such as osteoporosis and fracture. This study is designed to assess the effect of estrogen treatment, folic acid supplementation on bone markers in ovariectomized (ovx) rats.

Fifty adult female rats were divided into five equal groups: one served as control, the rats in the second group were subjected to ovariectomy, the third group were exposed to ovariectomy and treated with estrogen, the fourth group were ovariectomized and supplemented with folic acid and the fifth group were consist of ovariectomized rats treated with estrogen and supplemented with folic acid.

Ovariectomized rats showed insignificant increase in serum ca +2 and osteocalcin levels with significant decrease in serum vitamin D3 (vit.D3) and significant increase in alkaline phosphates activity and homocysteine levels.

Estrogen treatment of ovariectomized rats showed a significant decrease in serum homocysteine (Hcy) levels, alkaline phosphates activity accompanied with insignificant decrease in serum ca +2 , vit.D3 and osteocalcin than ovariectomized rats.

Supplementation of folic acid to ovariectomized rats induced significant increase in osteocalcin and decreased Hcy levels, insignificant changes in serum ca +2 , vit. D3 and alkaline phosphates than ovariectomized control rats, while combined treatment of ovariectomized rats with estrogen and folic acid exhibit better action on bone turnover with marked decrease in Hcy level.

So, we can conclude that, supplementation of folate with estrogen treatment has a beneficial effect for menopausal women to avoid osteoporosis and fracture.

Keywords: osteoporosis, ovariectomy, fructure, homocysteine, bone markers, bone turnover, osteocalcin.

\section{INTRODUCTION}

Primary osteoporosis is an age related disorder characterized by decreased bone mass and increased susceptibility to fractures in the absence of other recognizable causes of bone loss, Zengin A. et al. (2010).

The risk of developing osteoporosis increases with age and is higher in women than in men. Among the many possible contributors to primary osteoporosis, estrogen and calcium deficiencies and they are considered to be the most important causes, Coxam V. (2005). During menopause bone remodeling is increased and agents that suppress bone resorption can stabilize

bone mass, Canalis E. (2010). Estrogen is usually thought to maintain bone mass by inhibiting bone resorption and formation.

Estrogen deficiency at menopause increased bone turnover with loss throughout the skeleton. A number of theories have been proposed including imbalanced turnover at the level of basic multicillular unit of bone remodeling with a greater level of bone resorption relative to bone formation, Deal C. (2009).

In addicting, the increase in plasma homocysteine levels with menopause suggests a close relationship between homocysteine metabolism and estrogen status, Bednarek-Tupikowska G. et al. (2005).
\end{abstract}


Recently, hyperhomocysteinemia (HHcy) has been suggested to have adverse effects on bone and HHcy in rats induces accumulation of Hcy in bone tissue that is accompanied by bone loss, Herrmann M. et al. (2009).

With mild to moderate hyperhomocysteinemia, increased bone resorption by osteoclasts may contribute osteoporosis with an impaired biomechanical quality of the healing bone, Claes L. et al. (2009).

Estrogen replacement therapy is claimed to reduce bone turnover, increase bone mineral density and decreases vertebral and hip fractures rates, Iwamoto, J. et al. (2003) and Lindsay, R. et al. (2005).

Part of the risk for osteoporosis in women is established by their unhealthy life style in the premenopausal period, Vos, H. M. et al. (2010).

Folic acid supplementation reducing an elevated homocystein levels. So, folic acid and B vitamin may help to reverse the problems associated with hyperhomocysteinmia, Righetti, M. (2009).

So, the aim of this study was to evaluate the effect of ovariectomy, estrogen, folic acid supplementation on bone metabolism in intact and ovariectomized adult female rats by measuring indices of bone resorption and bone formation (bone biomarkers) and histopathologyical examination.

\section{MATERIALS AND METHODS}

The present study conducted on experimental animals.

In this work 50 mature female albino rats weighting $200 \pm 50 \mathrm{gm}$ were housed under the prevailing atmospheric conditions allover the experimental period in the laboratory of physiology.

\section{Experimental procedure:}

Ovariectomy of rats were done for 40 rats as described by, Oh H.Y. et al. (2007) and Vos H.M. et al. (2010) rats served without ovariectomy (intact).

Rats were divided into equal groups after two weeks of ovariectomy as follow: Group I: Intact rats served as a control (I) Group II: Ovariectomized rats served as a control (II)

Group III: Ovariectomized rats received daily $2 \mathrm{mg}$ of conjugated estrogen orally, Cagnacci, A. et al. (2006).
Group IV: Ovariectomized rats received normal diet fortified with folic acid powder in a dose $7.5 \mathrm{mg}$ /day, Villa, P. et al. (2005).

Group V: Ovariectomized rats received daily the same dose of estrogen orally and maintained on the diet fortified with folic acid powder.

Blood samples will obtained from the retro-orbital sinus all over night fasted rats under light ether anesthesia with capillary tubes.

Blood immediately centrifuged and serum will collected and stored at $-20^{\circ} \mathrm{c}$. until assayed for estimation of the following:

1- Calcium ions concentrations.

2- Vitamin D3 levels.

3- Osteocalcin hormone concentrations.

4- Activity of alkaline phosphatase.

5- Homocysteine levels.

Also, Histopathological examination of bones will be done.

\section{RESULTS}

The present work revealed insignificant increase in serum $\mathrm{C}+2$ concentration, significant decrease in the serum vit. D3 and significant increase alkaline phosphates activity with insignificant changes in osteocalcin level (Table 1 and Fig. 1). Also, we observed a relationship between elevated homocysteine level and bone markers of osteoporosis in ovariectomized rats (Table 2 and Fig. 2).

As regard to estrogen treatment, our study showed a significant decrease in serum Hcy, alkaline phosphates accompanied with insignificant decrease in serum ca +2 , vit. D3 and osteocalcin level when compared to ovariectomized rats.

In this research supplementation of folic acid alone to ovariectomized rats induced insignificant increase in serum calcium level when compared to both control groups, insignificant decrease in vit. D3 and alkaline phosphates with significant increase in osteocalcin hormone in comparison to ovariectomized rats.

The present study proved that combined administration of conjugated estrogen with supplementation of folic acid exhibit better action on bone turnover and prevents the loss of bone caused by estrogen deficiency in ovariectomized rats. 
(1): Effect of folic acid administration on serum calcium (mmol/l), vit.D3 (ng/ml), osteocalcin ( $\mathrm{ng} / \mathrm{ml}$ ) and alkaline phosphatase activity $(\mathrm{u} / \mathrm{l})$ in normal rats, Ovariectomized and Ovariectomized treated with estrogen.

\begin{tabular}{|c|c|c|c|c|c|c|c|c|c|c|c|c|}
\hline \multirow[t]{2}{*}{ Parameter } & \multicolumn{3}{|c|}{ Calcium } & \multicolumn{3}{|c|}{ Vitamen D3 } & \multicolumn{3}{|c|}{ osteocalcin } & \multicolumn{3}{|c|}{ Alkaline phosphatase } \\
\hline & 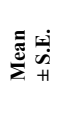 & 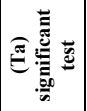 & 金莺莺 & 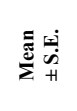 & 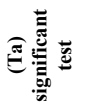 & 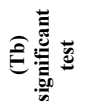 & 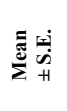 & 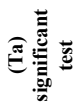 & 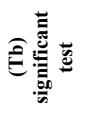 & 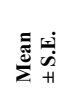 & 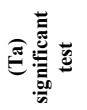 & 金莺 \\
\hline Control & $\begin{array}{c}2.681 \\
\pm \\
0.057\end{array}$ & - & 0.884 & $\begin{array}{c}105.60 \\
\pm \\
2.420\end{array}$ & - & $0.000^{*}$ & $\begin{array}{c}4.515 \\
\pm \\
0.258\end{array}$ & - & 0.846 & $\begin{array}{c}140.8 \\
\pm \\
12.351\end{array}$ & - & $0.00^{*}$ \\
\hline Ovariectomized & $\begin{array}{c}3.186 \\
\pm \\
0.470\end{array}$ & 0.110 & - & $\begin{array}{c}61.926 \\
\pm \\
6.614\end{array}$ & $0.000^{*}$ & - & $\begin{array}{c}4.304 \\
\pm \\
0.340\end{array}$ & 0.846 & - & $\begin{array}{c}240.4 \\
\pm \\
6 . .930\end{array}$ & $0.000 *$ & - \\
\hline $\begin{array}{l}\text { Ovariectomized treated with } \\
\text { estrogen }\end{array}$ & $\begin{array}{c}2.725 \\
\pm \\
0.039 \\
\end{array}$ & 0.884 & 0.130 & $\begin{array}{c}54.401 \\
\pm \\
4.535 \\
\end{array}$ & $0.000^{*}$ & 0.378 & $\begin{array}{c}3.877 \\
\pm \\
0.259\end{array}$ & 0.571 & 0.704 & $\begin{array}{c}155.4 \\
\pm \\
5.820\end{array}$ & 0.337 & $0.00^{*}$ \\
\hline $\begin{array}{l}\text { Ovariectomized treated with } \\
\text { folic acid }\end{array}$ & $\begin{array}{c}2.769 \\
\pm \\
0.083\end{array}$ & 0.778 & 0.884 & $\begin{array}{c}59.916 \\
\pm \\
8.131\end{array}$ & $0.000^{*}$ & 0.813 & $\begin{array}{c}6.437 \\
\pm \\
0.627\end{array}$ & 0.094 & $0.065^{*}$ & $\begin{array}{c}124.1 \\
\pm \\
15.079\end{array}$ & 0.270 & $0.00^{*}$ \\
\hline $\begin{array}{l}\text { Ovariectomized treated with } \\
\text { estrogen and folic acid }\end{array}$ & $\begin{array}{c}2.573 \\
\pm \\
0.028\end{array}$ & 0.737 & 0.627 & $\begin{array}{c}81.363 \\
\pm \\
6.950\end{array}$ & $0.007^{*}$ & $0.027^{*}$ & $\begin{array}{c}6.246 \\
\pm \\
1.682\end{array}$ & 0.130 & $0.091^{*}$ & $\begin{array}{c}104.2 \\
\pm \\
10.844\end{array}$ & $0.025^{*}$ & $0.00^{*}$ \\
\hline
\end{tabular}

The mean difference is significant at the 0.05 level.

(Ta): significant as compared with normal control group.

(Tb): significant as compared with Ovariectomized group.

Table 2: Effect of folic acid administration on serum homocysteine levels (Umol/L) in normal rats, ovariectomized and ovariectomized treated with estrogen.

\begin{tabular}{|l|c|c|c|}
\hline \multirow{2}{*}{ Parameter } & \multicolumn{3}{|c|}{ Homocysteine } \\
\cline { 2 - 4 } Group & Mean \pm S.E. & (Ta) significant test & (Tb) significant test \\
\hline Control & $15.463 \pm 0.751$ & - & $0.000^{*}$ \\
\hline Ovariectomized & $23.075 \pm 1.114$ & $0.000^{*}$ & - \\
\hline $\begin{array}{l}\text { Ovariectomized treated with } \\
\text { estrogen }\end{array}$ & $19.738 \pm 0.380$ & $0.011^{*}$ & $0.042^{*}$ \\
\hline $\begin{array}{l}\text { Ovariectomized treated with folic } \\
\text { acid }\end{array}$ & $11.338 \pm 1.721$ & $0.013^{*}$ & $0.000^{*}$ \\
\hline $\begin{array}{l}\text { Ovariectomized treated with } \\
\text { estrogen and folic acid }\end{array}$ & $9.243 \pm 1.238$ & $0.001^{* *}$ & $0.000^{*}$ \\
\hline
\end{tabular}

The mean difference is significant at the 0.05 level .

(Ta): significant as compared with normal control group.

(Tb): significant as compared with ovariectomized group.
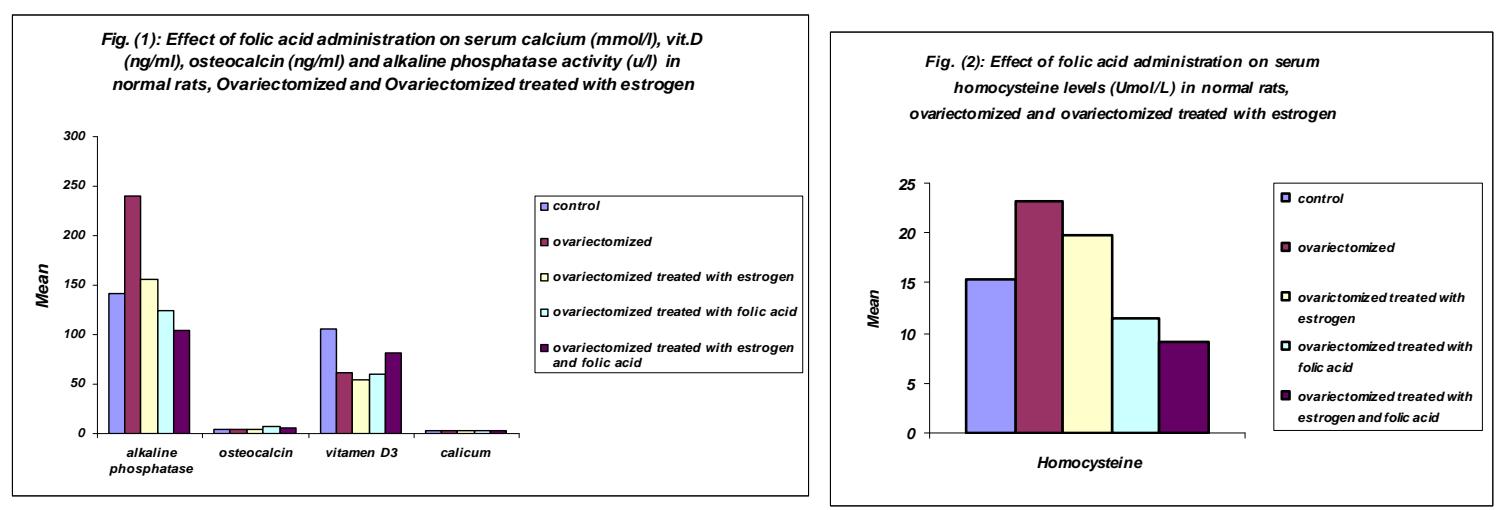


\section{Histological Results:}

In normal control group, histological examination of the cancellus and compact bone revealed normal architecture of bone cells and matrix (Figs. $3 a \& 3 b)$.

On the other hand, ovariectomized rats showing an increased number of osteoclast cells with abnormal matrix in the cancellus and compact bone with cavity formation (Figs. $4 \mathrm{a} \& 4 \mathrm{~b}$ ).

Ovariectomized rats treated with estrogen alone or combined with folic acid revealed less degenerative changes with less number of osteoclast cells (Figs. 5a \& 5b).

\section{DISCUSSION}

The data from this study showed that indices of both bone resorption and formation increased markedly after ovariectomy.

The insignificant increase in serum ca +2 after ovariectomy may be due to enhancement of osteoclasts and increased number of mature osteocasts, with continues release of calcium and phosphate as well as peptides from the bone matrix.

Our results are consistent with, Ahlborg, H.G. et al. (2001) who found specific differences in calcium homeostasis in osteoporotic subjects.

A negative calcium balance may be attributed to a primary process within the bone, with secondary consequences on the renal and gut handling of calcium or due to abnormalities in other organs and hormones regulating extracellular calcium homeostasis, mainly parathormon hormone PTH and osteocalcin hormone.

Also, (PTH) causes an increase of intestinal calcium absorption through its action on vit.D3. The active ca+2 absorption in the duodenum is under the control of 1, $25(\mathrm{OH} 2) \mathrm{D}$, and the vit. D3 metabolite increases the intestinal cell synthesis of ca +2 binding protein which enhances the net absorption of $\mathrm{ca}+2$. PTH also, decreases osteoblastic collagen synthesis, but osteoclastic bone resorption increases with a net increase of mineral release from bone into the extra cellular fluid, Kim D.J. et al. (2006).

The study of, Lee Y.M. et al. (2005) reported that decreased estrogen level in female increased the sensitivity of bones to the action of PTH leading to bone resorption with lower bone mineral density, Krivosíková Z. et al. (2010).

In contrast, serum ca++ level decreased in post menopausal women in the study of, Aspray T.J. e t al. (2005).

Also, Xie F. et al. (2005) have reported a decreased serum ca+2 after ovariectomy in rats and the increased bone resorption does not appear to occur but the process of bone turnover increased. The present work revealed significant increase in the serum vit. D3 and alkaline phosphatase with insignificant changes in osteocalcin level in ovariectomized rats. This result may be explained by the increased bone resorption due to an increase sensitivity of bone to PTH as a result of decreased plasma estrogen after ovariectomy and increased level of Hcy, Herrmann M. et al. (2007).

Concerning the increased alkaline phosphatase and vit. D3 after ovariectomy indicates an increased osteoblastic activity on bone formation. In accordance, Arshad, M. et al. (2004), found a relationship between serum alkaline phosphatase and age, with marked rise after the first decade of menopause, also, Aspray T. J. et al. (2005), reported an increase in alkaline phosphatase activity after few days of ovariectomy.

The insignificant decrease in serum concentration of osteocalcin may be due to bone resorption after ovariectomy, Cardenas Morales B.E. and E. Perez Campos (2003) and Mizoguchi T. et al. (2007), found the same results after 9 weeks of ovariectomy. Also, Ozdem S. et al. (2007), found that bone formation marker (osteocalcin) decreased in rats with hyperhomocysteinemia (HHcy) due to bone resorption.

Inconssistent with our results, Hankenson K.D. et al. (2005), who found an elevation in ostecalcin concentration after 2 weeks of ovariectomy but its level decreased after five weeks and they explained these results by increased the process of bone formation.

Also, Seifert-Klauss V. et al. (2005), were observed increased serum osteocalcin in premenopausal women and 
attributed that to increased bone loss before postmenopause as a result of increased ovulatory cycles.

The adverse effects of aging on the skeleton such as oxidative stress, are the fundamental mechanisms of the decline of bone mass and strength and osteocyte death is major contributor to the decline bone strength with age, Manolagas S.C. and A.M. Parfitt (2010). Studies in animals and humans suggest that homocysteine may weaken the collagen crosslink's and, if present in large amounts, interfere with bone remodeling, Herrmann M. et al. (2007) and Levasseur R. (2009).

In this study, we observed a relationship between hyperhomocysteinemia and the bone marker of osteoporosis in ovariectomized rats may be attributed to loss of estrogens that accelerates effect of aging on bone by decreasing defense against oxidative stress, Almeida M. et al. (2007).

Homocysteine directly activates osteoclasts formation and activity through increased generation of intracellular reactive oxygen species, Cagnacci A. et al. (2008). Also, elevated Hcy is associared with reduced bone mineral density especially with bone fracture. Golbahar J. et al. (2005), suggested that HHcy and low folate associated with osteoporosis in postmenopausal women. Findings of, Kim D. J. et al. (2006), revealed that high plasma Hcy induced apoptotic effect on osleoblasts.

The results of, Herrmann M. et al. (2005) demonstrated week, but significant relations between Hcy and markers of organic and inorganic bone resorption, suggesting a mechanistic role of Hcy in bone metabolism.

The data of the present study showed a significant decrease in serum Hcy, alkaline phosphatase accompanied with insignificant decrease in serum ca +2 , vit. D3 and increased osteocalcin level after estrogen treatment to ovariectomized rats. This effect was explained by, Bednarek-Tupikowska G. et al. (2005), that estrogen have a profound influence on Hcy and lipid peroxides and concluded that Hcy level controlled by administration of hormone replacement therapy.
From other hand, Baines M. et al. (2007), reported that low serum folate is a significant risk factor for osteoporosis, and supplementation of folic acid may have an effect on the skeleton in postmenopausal women. While, Kim D.J. et al. (2006), suggest that methionine synthase reductase (MTRR) is an enzyme involved in the conversion of Hcy to methionine and they hypothesized that certain genetic polymorphisms of MTRR leading to reduced enzyme activity may cause hyperhomocysteinemia and affect bone metabolism in postmenopausal women.

Also, Cagnacci A. et al. (2003), found a major association between folate and bone mineralization and high dietary intake of folate exerts positive effect on bone mineral density. Recent studies in rodents indicate that aging and the associated increase in reactive oxygen species (Ros) are the proximal culprits because it influence the generation and survival of osteoclasts, osteoblasts and osteocyte and loss of estrogen decreases defense against oxidative stress in bone and this accounts for increase bone resorption associated with loss of estrogen so, estrogen treatment may improve bone formation. In addition, increased glucocorticoid production and sensitivity with advancing age decrease skeletal hydration and thereby increase skeletal fragility by attenuating the volume of bone vasculature and interstitial fluid, Manolagas S.C. (2010).

In the present research supplementation of folate alone to ovariectomized rats induced return the calcium level, vit. D3 concentration to the normal value, accompanied with significant increase in osteocalcin level and significant decrease in alkaline phosphatase activity. This data indicates an improvement in bone formation. This effects was explained by, Wolters M. et al. (2004), that folic acid act as coenzymes and show a close molecular interaction of the bases of the Hcy metabolism.

The data of, Rejnmark L. et al. (2008), are in agreement with our results, they reported a positive association between nutrient dense (intake of fruits, vegetable and whole grain) and bone health.In addition, Levasseur R. (2009), 
suggest that folate supplementation to patients with HHcy may improve not only bone health, but also general health.

Also, Chen K.J. et al. (2005), suggest that poor folate and B6 has a synergistic effect on the risk of HHcy in elderly male and female. Also, the study of, Herrmann M. et al. (2009), on rats found that folate deficiency induced HHcy but has no effect on bone health in healthy adult rats.

The present study proved that combined estrogen and folic acid supplementation exhibit better action on bone turnover and prevent the loss of bone caused by estrogen deficiency in ovariectomized rats.

So, there is a possibility that folic acid could be added to estrogen as a HRT to be a novel anti osteoporosis drug for menopausal women.

Therefore, maintaining adequate folic acid should be emphasized as an important measure for reducing Hcy level among elderly people. Also, we recommended that administration of estrogen and folic acid has a beneficial effect to pre-and postmenopausal women to improve and prevent the occurrence of osteoporosis and fracture.

\section{Acknowledgement}

I wish to express my sincere gratitude and utmost thanks to the Dean of Scientific Research for funding this research.

\section{REFERENCES}

Ahlborg, H.G., O. Johnell, B.E. Nilsson, S. Jeppsson, G. Rannevik and M. K. karlsson (2001): Bone loss in relation to menopause: a prospective study during 16 years. Bone, 28:327-331. PMID: 11248665.

Almeida M., L. Han, M. Martin-Millan, L.I. Plotkin, S.A. Stewart, P.K. Roberson, S. Kousteni, C.A. O'Brien, T. Bellido, A.M. Parfitt, R.S. Weinstein, R.L. Jilka and S.C. Manolagas (2007): Skeletal involution by age-associated oxidative stress and its acceleration by loss of sex steroids. J Biol Chem. 282 (37): 27285-97. PMID: 17623659.

Arshad, M., S. Sengupta, S. Sharma, R. Ghosh, V. Sawlani and M.M. Singh (2004): In vitro antiresorpetive activity and prevention of ovareictomy induced osteoporosis in female Sprague-Dawley rats by ormelxifene a selective estrogen receptor modulator. J. Steroid. Biochem. Mol. Biol. 91(12): 67-78._PMID: 15261309.

Aspray T.J., L. Yan and A. Prentice (2005): Parathyroid hormone and rates of bone formation are raised in perimenopausal rural Gambian women. Bone, 36(4): 710-720. PMID: 15780975.

Baines M., M.B. Kredan, J. Usher, A. Davison, G. Higgins, W. Taylor, C. West, W.D. Fraser and L.R. Ranganath (2007): The association of homocysteine and its determinants MTHFR genotype, folate, vitamin B12 and vitamin B6 with bone mineral density in postmenopausal British women. Bone. 40(3):730-6. PMID: 17141597.

Bednarek-Tupikowska G., K. Tupikowski, B. Bidzińska, J. Kuliczkowska, A. Filus and A. Milewicz (2005): The effect of estrogen deficiency, estrogen and estro-progestagene therapy on total plasma homocysteine and serum lipid peroxide levels in postmenopausal women. Ginekol Pol. 76(9):687-92. PMID: 16417079.

Cagnacci A, B. Bagni, A. Zini, M. Cannoletta, M. Generali and A. Volpe (2008): Relation of folates, vitamin B12 and homocysteine to vertebral bone mineral density change in postmenopausal women. A five-year longitudinal evaluation. Bone. 42(2):314-20. PMID: 18289506.

Cagnacci A., F. Baldassari, G. Rivolta, S. Arangino and A. Volpe (2003): Relation of homocysteine, folate, and vitamin B12 to bone mineral density of postmenopausal women. Bone. 33(6):956-9. PMID: 14678855.

Cagnacci, A., M. Generali, D. Pirillo, F. Baldassari and A. Volpe (2006): Effects of low-or high-dose hormone therapy on fasting and postmethionine homocysteine levels in postmenopausal women. Climacteric., 9 (5) : 388-395 . PMID: 17000586.

Canalis E. (2010): New Treatment Modalities in Osteoporosis. Endocr 
Pract. 29:1-23. [Epub ahead of print]. PMID: 20350910.

Cardenas Morales B.E. and E. Perez Campos (2003): Bibliographic review. The role of hypoestrogenism in postmenopausal osteoporosis - new perspectives. Ginecol. Obstet. Mex. 71: 187-194. PMID: 12866220.

Deal, C. (2009): Potential new drug targets for osteoporosis. Nat Clin Pract Rheumatol. 5(1):20-7. PMID: 19098925.

Claes L., J. Schmalenbach, M. Herrmann, I. Olkü, P. Garcia, T. Histing, R. Obeid, H. Schorr, W. Herrmann, T. Pohlemann, M.D. Menger and J.H. Holstein (2009): Hyperhomocysteinemia is associated with impaired fracture healing in mice. Calcif Tissue Int. 85(1):17-21. PMID: 19533012.

Coxam V. (2005): New advances in osteoporosis nutritional prevention. Med Sci (Paris). 21(3):297-301. PMID: 15745705.

Chen K.J., W.H. Pan, F.L. Yang, I.L. Wei, N.S. Shaw and B.F Lin (2005): Association of B vitamins status and homocysteine levels in elderly Taiwanese. Asia Pac J Clin Nutr. 14(3):250-5. PMID: 16169836.

Golbahar J., M.A. Aminzadeh, S.A. Hamidi and G.R. Omrani (2005): Association of red blood cell 5methyltetrahydrofolate folate with bone mineral density in postmenopausal Iranian women. Osteoporos Int. 16(12):1894-8. PMID: 16133647.

Hankenson K.D., I.E. James, S. Apone, G.B. Stroup, S.M. Blake, X. Liang, M.W. Lark and P. Bornstin (2005): Increased osteoblastogenesis and decreased bone resorption protect against ovariectomy-induced bone loss in thrombospondin-2-null mice. Matrix Biolo. 24(5):362-370. PMID: 15979292.

Herrmann M., A. Tami, B. Wildemann, M. Wolny, A. Wagner, H. Schorr, O. TabanShomal, N. Umanskaya, S. Ross, P. Garcia, U. Hübner and W. Herrmann (2009): Hyperhomocysteinemia induces a tissue specific accumulation of homocysteine in bone by collagen binding and adversely affects bone. Bone. 44(3):467-75. PMID: 19056526.

Herrmann M., B. Wildemann, L. Claes, S. Klohs, M. Ohnmacht, O. Taban-
Shomal, U. Hübner, A. Pexa, N. Umanskaya and W. Herrmann (2007): Experimental hyperhomocysteinemia reduces bone quality in rats. Clin Chem. 53(8):1455-61. PMID: 17586593.

Herrmann M., M. Kraenzlin, G. Pape, M. Sand-Hill and W. Herrmann (2005): Relation between homocysteine and biochemical bone turnover markers and bone mineral density in peri- and post-menopausal women. Clin Chem Lab Med. 43(10):1118-23. PMID: 16197308.

Iwamoto J., T. Takeda, S. Ichimura and M. Uzawa (2003): Early response to alendronate after treatment with etidronate in postmenopausal women with osteoporosis. Keio J Med. 52(2):113-9. PMID: 12862363.

Kim D.J., B.L. Park, J.M. Koh, G.S. Kim, L.H. Kim, H.S. Cheong, H.D. Shin, J.M. Hong, T.H. Kim, H.I. Shin, E.K. Park and S.Y. Kim (2006): Methionine synthase reductase polymorphisms are associated with serum osteocalcin levels in postmenopausal women. Exp Mol Med. 38(5):519-24. PMID: 17079868.

Krivosíková Z., M. KrajcovicováKudlácková, V. Spustová, K. Stefíková, M. Valachovicová, P. Blazícek and T. Němcová (2010): The association between high plasma homocysteine levels and lower bone mineral density in Slovak women: the impact of vegetarian diet. Eur J Nutr. 49(3):147-53. PMID: 19809862.

Lee Y.M., P.Y. Cheng, S.F. Hong, et al. (2005): Oxidative stress induces vascular hemeoxygenase-1 expression in ovariectomized rats. Free Radic. Biol. Med. 39(1): 108-117._PMID: 15925283.

Levasseur R. (2009): Bone tissue and hyperhomocysteinemia. Joint Bone Spine. $\quad 76(3): 234-40 . \quad$ PMID: 19217816.

Lindsay R, Gallagher JC, Kleerekoper M, Pickar JH. (2005): Bone response to treatment with lower doses of conjugated estrogens with and without medroxyprogesterone acetate in early postmenopausal women. Osteoporos Int. 16(4):372-9. PMID: 15654581. 
Manolagas S.C. (2010): From EstrogenCentric to Aging and Oxidative Stress: A Revised Perspective of the Pathogenesis of Osteoporosis. [Epub ahead of print] Endocr Rev. PMID: 20051526.

Mizoguchi T., S. Nagasawa, N. Takahashi, H. Yagasaki and M. Ito (2005): Dolomite supplementation improves bone metabolism through modulation of calcim-regulating hormone secretion in ovariectomized rats. J. Bone Miner. Metab. 23(2): 140-146. PMID: 15750692.

Manolagas S.C. and A.M. Parfitt (2010): What old means to bone. Trends Endocrinol Metab. (Epub ahead of print). PMID: 20223679.

Oh H.Y., S. Lim, J.M. Lee, D.Y. Kim, E.S. Ann and S. Yoon (2007): A combination of soy isoflavone supplementation and exercise improves lipid profiles and protects antioxidant defense-systems against exercise-induced oxidative stress in ovariectomized rats. Biofactors. 29(4):175-85. PMID: 18057549.

Ozdem S., S. Samanci, A. Tasatargil, A. Yildiz, G. Sadan, L. Donmez and M. Herrmann (2007): Experimental hyperhomocysteinemia disturbs bone metabolism in rats. Scand J Clin Lab Invest. 67(7):748-56. PMID: 17852810 .

Rejnmark L, P. Vestergaard, A.P. Hermann, C. Brot, P. Eiken and L. Mosekilde (2008): Dietary intake of folate, but not vitamin B2 or B12, is associated with increased bone mineral density 5 years after the menopause: results from a 10 -year follow-up study in early postmenopausal women. Calcif Tissue Int. 82(1):1-11. PMID: 18175033.
Righetti M. (2009): Protective effect of vitamin B therapy on bone and cardiovascular disease. Recent Pat Cardiovasc Drug Discov. 4(1):37-44. PMID: 19149705.

Seifert-Klauss V., J. Laakmann, J. Rattenhuber, C. Hoss, et al. (2005): Bone metabolism, bone density and estrogen levels in perimenopause: a prospective 2-year-study. Zentralbl. Gynakol. 127(3): 132-139._PMID: 15915390.

Villa, P., C. Perri, R. Suriano, et al. (2005). L-folic acid supplementation in healthy postmenopausal women: effect on homocysteine and glycolipid metabolism. J. Clin. Endocrinol. Metab., 90 (8): 4622-4629. PMID: 15899950.

Vos H.M., A. van Kuik, M.E. Janse, F.G. Schellevis and T.L. Lagro-Janssen (2010): Prevention of coronary heart disease and osteoporosis in women aged 45 to 49 years: a challenging role for general practitioners.Menopause. 17(2):290-4. PMID: 20032797.

Wolters M., A. Ströhle and A. Hahn (2004): Age-associated changes in the metabolism of vitamin B (12) and folic acid: prevalence, aetiopathogenesis and pathophysiological consequences. Z Gerontol Geriatr. 37(2):109-35. PMID: 15103481.

Xie F., C.F. Wu, Y. Zhang, et al. (2005): Increase in bone mass and bone strength by Sambucus williamsii HANCE in ovareictomized rats. Biol. Pharm. Bull. 28(10): 1879-1885. PMID: 16204939.

Zengin A., L. Zhang, H. Herzog, P.A. Baldock and A. Sainsbury (2010): Neuropeptide $Y$ and sex hormone interactions in humoral and neuronal regulation of bone and fat. Trends Endocrinol Metab. [Epub ahead of print], PMID: 20202858. 


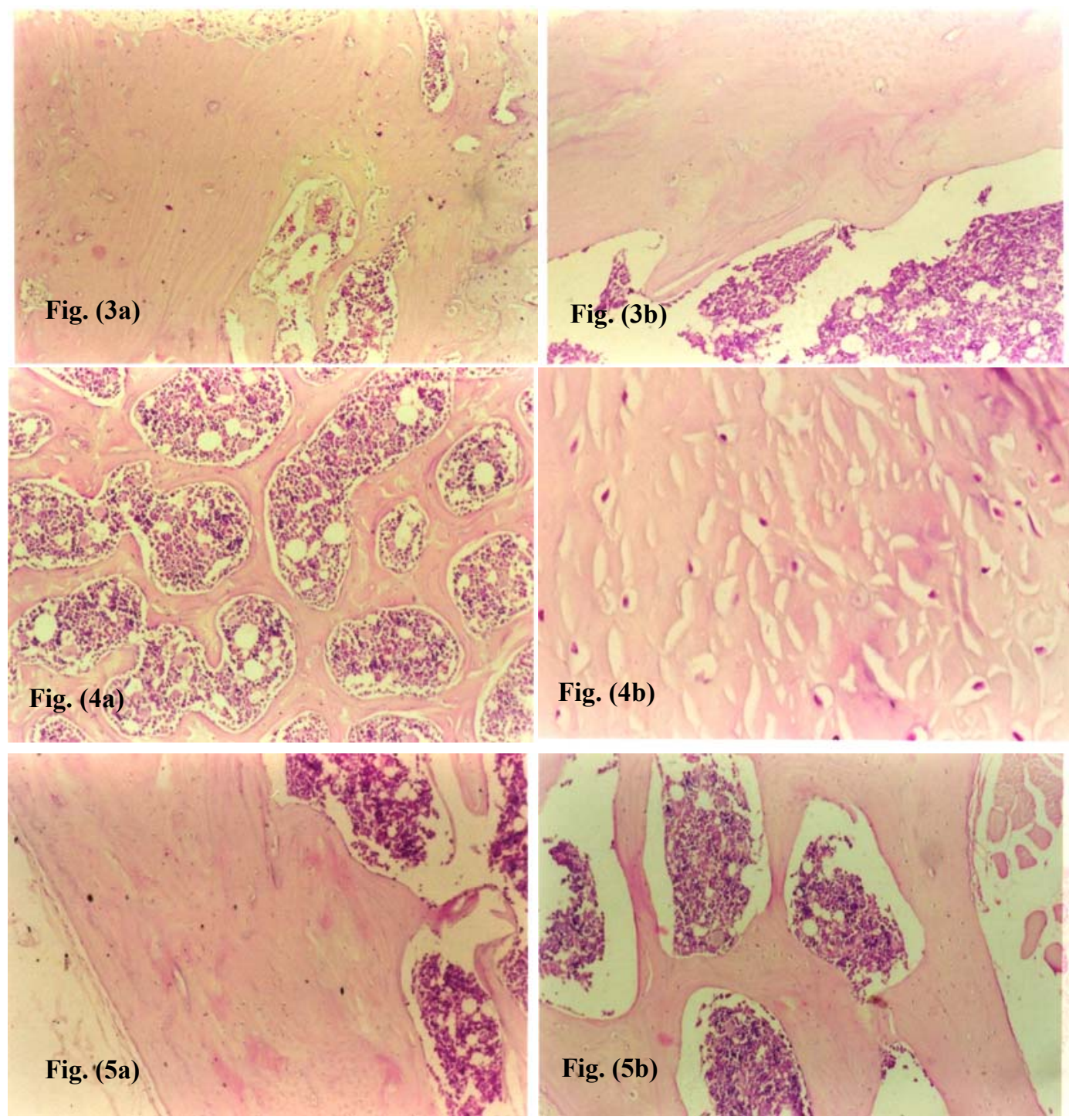

Figs. 3a \& 3b: Photomicrograph in normal control rats, in the cancellus and compact bone showing normal architecture of bone cells and matrix (H. \& E.x.125).

Figs. 4a \& 4b: Photomicrograph in ovariectomized rats showing an increased number of osteoclast cells with abnormal matrix in the cancellus and compact bone with cavity formation (H. \& E.x.125).

Figs.5a \& 5b: Photomicrograph in ovariectomized rats treated with estrogen alone or combined with folic acid showing less degenerative changes with less number of osteoclast cells (H. \& E.x.125). 


\section{ARABIC SUMMARY}

تأثير التغنية التكميلية بحض الفوليك على دلالات هشاثة العظام في الجرذان مستأصلة المبايض

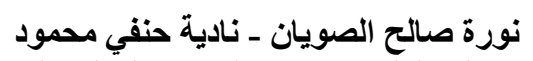

قسم البيولوجيا ، كلية العلوم ، جامعة القصيم، المملكة العربية السعودية.

يعتبر سن اليأس من التغير ات الطبيعية التي تحدث في الحياة ، و التي قد تكون مصحوبة بمشـاكل صحية عديدة

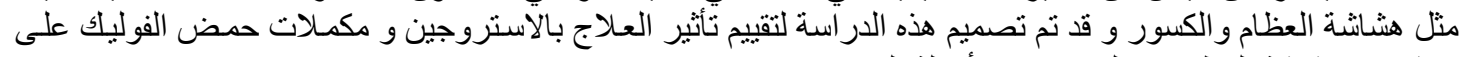

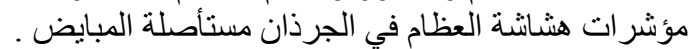

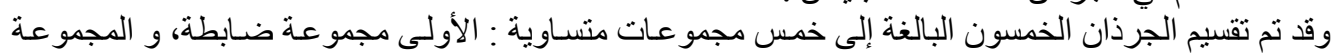

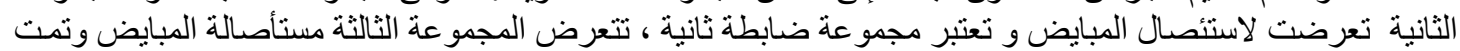

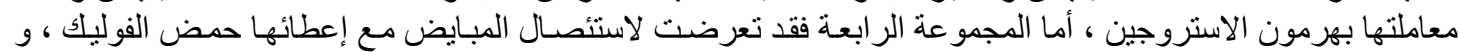

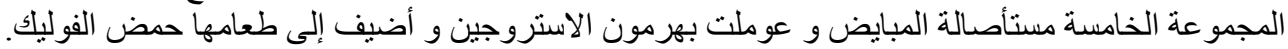

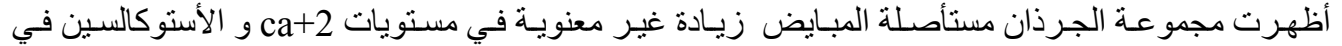
المصل مع انخفاض معنوي في مستوى vit. D3 في المصل ، وارتفاع ذو دلانلة معنوية في نشاط إنزيم الفوسفات القاعدي

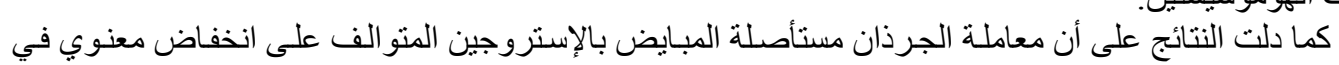

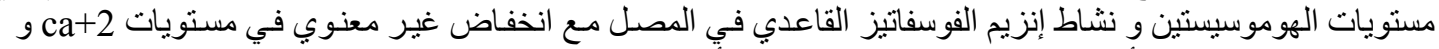

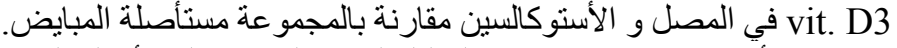

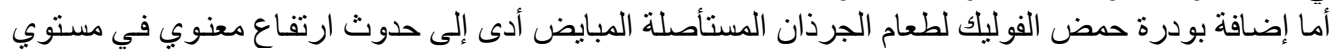

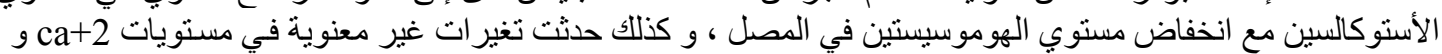
و vit. D3

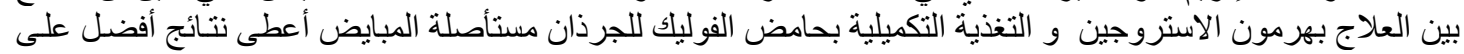

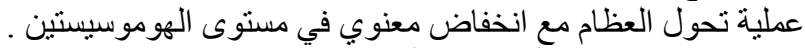

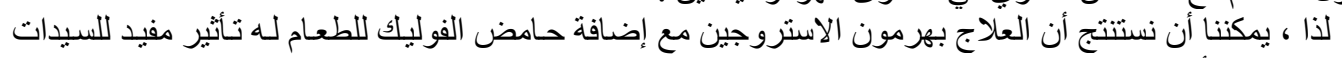
المقبلات على سن اليأس لتجنب حدوث هشآنشة العظام و الكسور. 